\title{
Extern rendement basiseducatie
}

Citation for published version (APA):

Jacob-Tacken, K. H. M., \& Wolbers, M. H. J. (2000). Extern rendement basiseducatie. Researchcentrum voor Onderwijs en Arbeidsmarkt, Faculteit der Economische Wetenschappen. ROA Working Papers No. 2 https://doi.org/10.26481/umarow.2000002

Document status and date:

Published: 01/01/2000

DOI:

10.26481/umarow.2000002

Document Version:

Publisher's PDF, also known as Version of record

\section{Please check the document version of this publication:}

- A submitted manuscript is the version of the article upon submission and before peer-review. There can be important differences between the submitted version and the official published version of record.

People interested in the research are advised to contact the author for the final version of the publication, or visit the DOI to the publisher's website.

- The final author version and the galley proof are versions of the publication after peer review.

- The final published version features the final layout of the paper including the volume, issue and page numbers.

Link to publication

\footnotetext{
General rights Owners
rights.

- You may freely distribute the URL identifying the publication in the public portal. please follow below link for the End User Agreement:

www.umlib.nl/taverne-license

Take down policy

If you believe that this document breaches copyright please contact us at:

repository@maastrichtuniversity.nl

providing details and we will investigate your claim.
}

Copyright and moral rights for the publications made accessible in the public portal are retained by the authors and/or other copyright owners and it is a condition of accessing publications that users recognise and abide by the legal requirements associated with these

- Users may download and print one copy of any publication from the public portal for the purpose of private study or research.

- You may not further distribute the material or use it for any profit-making activity or commercial gain

If the publication is distributed under the terms of Article $25 \mathrm{fa}$ of the Dutch Copyright Act, indicated by the "Taverne" license above, 


\section{Extern Rendement Basiseducatie}

ROA-W-2000/2

Karin Jacob-Tacken en Maarten Wolbers

Researchcentrum voor Onderwijs en Arbeidsmarkt

Faculteit der Economische Wetenschappen en Bedrijfskunde Universiteit Maastricht

Maastricht, maart 2000 
ISBN 90-5321-276-0

SEC00.030/MW 
Inhoud

Bladzijde

1 Inleiding 1

$\underline{2}$ Ontwikkeling vragenlijst 2

$\underline{3}$ Uitkomsten 3

3.1 Algemeen 3

3.2 Gevolgde opleiding $\quad 4$

$\begin{array}{lll}3.3 & \text { Vervolgopleiding } & 4\end{array}$

3.4 Bestemming 5

3.5 Kenmerken huidige werkzaamheden 5

3.6 Sociale redzaamheid 5

4 Besluit $\quad 6$

$\begin{array}{lr}\text { Bijlage } 1 \text { Kerngetallen cursussen Basiseducatie } & 9\end{array}$

Bijlage 2 Telefonische vragenlijst Basiseducatie (BMF, NT2 en SR) 



\section{Inleiding}

Binnen het Researchcentrum voor Onderwijs en Arbeidsmarkt (ROA) is in de loop van de jaren een zogenoemd schoolverlatersinformatiesysteem ontwikkeld, afgekort als SIS, dat bestaat uit de schoolverlatersenquêtes Registratie van Uitstroom en Bestemming van Schoolverlaters (RUBS), HBO-monitor en WO-monitor. Dit informatiesysteem bevat momenteel representatieve gegevens over schoolverlaters van het AVO, VBO, de beroepsopleidende en beroepsbegeleidende leerweg van het secundair onderwijs (BOL en $\mathrm{BBL})$, het $\mathrm{HBO}$ en WO. Een ontbrekende groep schoolverlaters in SIS zijn de cursisten van de Educatie, zoals gedefinieerd in de Wet Educatie en Beroepsonderwijs (WEB) van 1 januari 1996. In deze wet is onder andere het begrip 'volwasseneducatie' geherdefinieerd tot Educatie. Educatie is gericht op persoonlijke ontplooiing van volwassenen ten dienste van hun maatschappelijke functioneren. Het primaire doel van Educatie is het wegwerken van achterstanden die deelname aan de steeds ingewikkelder samenleving bemoeilijken. Educatie vindt plaats binnen regionale opleidingencentra (ROC's). Binnen Educatie worden vier onderwijstypen onderscheiden:

- Voortgezet algemeen volwassenenonderwijs (VAVO);

- Opleidingen gericht op breed maatschappelijk functioneren (BMF);

- Opleidingen Nederlands als tweede taal (NT2);

- Opleidingen gericht op sociale redzaamheid (SR).

De VAVO-opleidingen zijn bedoeld voor (jong-)volwassenen die een diploma of deelcertificaat MAVO, HAVO of VWO willen behalen. De opleidingen BMF, NT2 en SR vallen onder de Basiseducatie (BE). Daarbij zijn de opleidingen BMF en NT2 vooral bedoeld om achterstanden weg te werken en vervolgens doorstroming naar vervolgonderwijs en beroep mogelijk te maken. De opleidingen gericht op SR zijn vooral bedoeld om de zelfredzaamheid van een individu binnen de maatschappij te bevorderen. Alle opleidingen BE zijn gericht op het behalen van officieel vastgestelde eindtermen. Deze eindtermen zijn opgenomen in een kwalificatiestructuur, op grond waarvan aansluiting mogelijk is met het overige onderwijs.

Om de groep cursisten van de Educatie te kunnen betrekken in SIS zijn in de afgelopen jaren twee pilot projecten uitgevoerd. Allereerst heeft eind 1997 een schriftelijke enquête plaatsgevonden onder cursisten van de VAVO. Een onderzoek onder cursisten van de BE was niet goed mogelijk in deze opzet. Met name de groep allochtonen, die een omvangrijk deel vormt van de uitstroom van de BE, is vanwege problemen met de Nederlandse taal moeilijk te benaderen middels een Nederlandstalige schriftelijke vragenlijst. Daarom heeft begin 1999 een apart verkennend onderzoek onder cursisten van de BE plaatsgehad. De nadruk van deze pilot lag daarbij op het ontwikkelen en testen van het instrument (ontwikkeling vragenlijst, kleinschalige enquête, evaluatie). In deze notitie wordt beknopt verslag gedaan van de resultaten van de pilot onder cursisten van de BE. Naast een beschrijving van het ontwikkelen van de vragenlijst en de afname daarvan, wordt enig cijfermateriaal gepresenteerd dat een beeld geeft van de belangrijkste resultaten van het uitgevoerde onderzoek. De notitie wordt besloten met een drietal conclusies. 


\section{Ontwikkeling vragenlijst}

Voorafgaand aan het opstellen van de vragenlijst heeft overleg over de globale opzet van de vragenlijst plaatsgevonden met enkele deskundigen van één van de aan het onderzoek deelnemende ROC's. Tijdens dit gesprek is aan de orde gekomen welke informatie voor onderwijsinstellingen relevant is. Naast het verschaffen van inzicht in het externe rendement van de cursussen (zoals gebruikelijk is in het reguliere schoolverlatersonderzoek van het ROA), werd het vooral wenselijk geacht om het subjectieve oordeel van de cursisten over de gevolgde cursus vast te stellen (het algemeen nut van de cursus). Met name bij cursussen $\mathrm{SR}$, die niet primair doelen op doorstoom naar vervolgonderwijs en/of (her-)intrede op de arbeidsmarkt, levert algemene informatie over het nut van de cursus interessantere gegevens op dan cijfers over harde rendementscriteria.

Naar aanleiding van bovengenoemd overleg is een conceptvragenlijst opgesteld. Er is gekozen voor een telefonische vragenlijst om een zo hoog mogelijke respons te verkrijgen. De belangrijkste reden voor een telefonische enquête is dat allochtonen, die een groot deel vormen van de uitstroom van de cursussen $B E$, vanwege lees- en schrijfproblemen met het Nederlands moeilijk te benaderen zijn door middel van een Nederlandstalige schriftelijke vragenlijst. Bovendien kan bij een telefonische enquête, wanneer blijkt dat een respondent geen Nederlands verstaat, een tolk worden ingezet die de taal spreekt van de desbetreffende respondent.

Er is verder besloten om in de vragenlijst expliciet onderscheid te maken tussen de cursussen BMF, SR en NT2. De reden hiervoor is dat voor elk cluster van cursussen andere zaken van belang zijn. De cursussen die onder BMF vallen zijn veelal bedoeld als opstap voor een vervolgopleiding of werk. Ook het leren van Nederlands als tweede taal (NT2) kan een opstap zijn naar een vervolgopleiding of werk. Voor beide uitstroommogelijkheden zijn aparte vragenblokken opgenomen in de vragenlijst. De cursussen die onder SR vallen zijn daarentegen meer gericht op persoonlijke ontplooiing en deelname aan het maatschappelijk verkeer. Voor de laatste groep (SR) is hierover dan ook een apart blok met vragen ontwikkeld. Bovendien zijn voor deze groep cursisten vragen omtrent vervolgonderwijs en activiteiten op de arbeidsmarkt buiten beschouwing gelaten.

Deze werkwijze impliceert dat op voorhand de drie clusters van cursussen moesten worden onderscheiden. Dit was niet altijd even gemakkelijk. De aangeleverde informatie verschilde af en toe, omdat ROC's de cursussen op verschillende manieren kunnen clusteren. Vooral het onderscheid tussen SR en BMF bleek soms moeilijk te maken: bij sommige ROC's behoren alle cursussen die niet onder NT2 vallen tot de categorie BMF, terwijl bij andere ROC's alle cursussen die niet betrekking hebben op NT2-onderwijs zijn ingedeeld bij SR. Hierdoor kan een soortgelijke cursus bij het ene ROC vallen onder BMF en bij het andere onder SR.

De conceptvragenlijst is vervolgens ter commentaar voorgelegd aan degenen met wie eerder de globale opzet van de vragenlijst is besproken. Daarna is in een breder kader (het reguliere RUBS-BVE Gebruikersoverleg), waarin vertegenwoordigers van verschillende 
ROC's, ROA, LDC Expertisecentrum voor loopbaanvraagstukken en DESAN Marktonderzoek aanwezig waren, de conceptvragenlijst doorgepraat. Ten slotte is er een proefafname van de telefonische enquête geweest onder enkele tientallen respondenten. Naar aanleiding hiervan is de vragenlijst definitief gemaakt.

De telefonische interviews vonden plaats in de periode van 27 januari tot en met 19 februari 1999. De ondervraagde cursisten, die in de periode december 1997 - juli 1998 een cursus in het kader van de BE hebben gevolgd, waren afkomstig van zeven verschillende ROC's. Deze ROC's hebben op basis van vrijwilligheid meegedaan aan het onderzoek. In ruil voor de geleverde administratiebestanden met daarin gegevens over de naam, het adres en de woonplaats van de cursisten (NAW-gegevens) hebben de participerende instellingen cijfermateriaal ontvangen met daarin de belangrijkste uitstroomgegevens over hun eigen cursisten. Het een en ander betekent dat de cijfers voor de afzonderlijke onderwijsinstellingen weliswaar representatief zijn, maar landelijk gezien niet. De landelijke cijfers zijn immers het gemiddelde van een selecte groep van deelnemende ROC's. De hieronder gepresenteerde landelijke cijfers dienen dan ook met voorzichtigheid te worden geïnterpreteerd.

In bijlage 1 zijn de belangrijkste uitkomsten in tabelvorm afgebeeld. In bijlage 2 is de ontwikkelde vragenlijst weergegeven.

\section{Uitkomsten}

\subsection{Algemeen}

Van het totale adressenbestand van de zeven ROC's zijn 2.309 van de 3.342 cursisten gebeld. Dit leverde 961 geslaagde gesprekken op (responspercentage van 42\%), waarvan 839 cursisten daadwerkelijk een cursus hebben gevolgd in de desbetreffende periode. Het blijkt echter, dat slechts 807 van de 839 cursisten de naam van de betreffende cursus hebben opgegeven. Alleen deze cursisten zijn opgenomen in het onderzoeksbestand.

Er blijken vooral veel cursussen Nederlands als tweede taal te worden gegeven: 335 van de 807 cursisten volgt een cursus binnen de categorie NT2. Vrouwen volgen vaker cursussen in het kader van BE $(64,5 \%)$ dan mannen $(35,5 \%)$. Bij de categorie NT2 is de verhouding vrouw/man (56,7\% vrouwen tegenover $43,3 \%$ mannen) het meest evenredig verdeeld. Verder valt op dat met name jongeren $(73,6 \%)$ een cursus binnen de categorie NT2 volgen, terwijl binnen de andere cursuscategorieën de oudere groep vaker is vertegenwoordigd $(69,7 \%$ en $63,4 \%)$.

Volgens de definitie van de Wet Bevordering Evenredige Arbeidsdeelname Allochtonen (WBEAA) wordt een persoon als allochtoon aangemerkt, wanneer minimaal twee van de volgende drie personen, te weten respondent, vader en moeder, zijn geboren in Aruba, Nederlandse Antillen, Ethiopië, Irak, Iran, voormalig Joegoslavië, Marokko, Somalië, Suriname, Turkije en Vietnam. Volgens deze definitie zijn er 257 allochtonen (31,8\%). Echter 
416 personen $(51,5 \%)$ spreken thuis een andere taal dan Nederlands. Daarom is ervoor gekozen om de lijst met landen van de WBEAA uit te breiden met de minder ontwikkelde landen uit Afrika (bijv. Zaïre), Zuid-Amerika (bijv. Colombia), Oost-Europa (bijv. Bulgarije) en Azië (bijv. Filippijnen). Cursisten die uit de meer ontwikkelde landen komen, zoals de WestEuropese landen, de Verenigde staten, China, Japan, Indonesië en Nederlands Indië, worden niet tot de groep allochtonen gerekend. Volgens deze verbrede definitie van de WBEAA zijn er 407 allochtonen (50,4\%). De groep allochtone cursisten is binnen de categorie NT2 het grootst $(74,1 \%)$.

\subsection{Gevolgde opleiding}

In de vragenlijst is de vraag gesteld welke cursus de respondenten hebben gevolgd. Dit is een open vraag, omdat van tevoren geen informatie beschikbaar was over de soort cursus die gevolgd is. Naderhand zijn de genoemde cursussen in tien groepen verdeeld, te weten:

- Oriëntatie- of opstapcursussen (oriëntatie- en schakelcursussen, arbeidsgewenning, cursus voor herintreding, huiswerkbegeleiding, etc.);

- Computercursussen;

- Nederlands als tweede taal voor mensen die nog geen Nederlands kunnen;

- Engels;

- Leren lezen, schrijven en rekenen;

- Nederlands voor autochtonen (nieuwe spelling, grammatica);

- Beroepsgerichte cursussen (informatica, administratie, MDGO-VP, etc.);

- Certificaten voor voortgezet onderwijs (MAVO Engels/Nederlands, certificaten biologie, economie, etc.);

- Basale kennis en vaardigheden (algemene ontwikkeling, eigen administratie, zelfstandig wonen cursus, etc.);

- Overige cursussen (levensverhalen, vrouwengroep, positief denken, naaicursus, etc.).

Vooral Nederlands als tweede taal is een cursus die veel wordt gevolgd $(52,8 \%)$. De meeste cursussen worden overdag gevolgd (73,6\%), vaak op eigen initiatief (70,6\%). De gemiddelde cursusduur is ruim een jaar. De waardering voor de cursussen, uitgedrukt in een rapportcijfer, bedraagt gemiddeld een 7,2 .

\subsection{Vervolgopleiding}

Van de 487 cursisten BMF en NT2 is 22,9\% een vervolgopleiding gaan doen. Hiervan doen de meeste cursisten een vervolgopleiding binnen BE $(38,4 \%)$, met name op het gebied van Kunst en Cultuur (18,2\%), Techniek (12.1\%) en Gedrag en Maatschappij (5,1\%). Ook stromen er een aantal cursisten door naar de BOL opleidingen Economie $(12,1 \%)$ en Techniek $(6,1 \%)$. lets minder dan de helft van de cursisten zegt veel aan de cursus te hebben gehad voor de vervolgopleiding $(48,2 \%)$. 


\subsection{Bestemming}

Slechts een relatief klein deel van de cursisten (182 van de 511) behoort officieel tot de beroepsbevolking. Hiertoe worden degenen gerekend, die 12 uur per week werken of teninste 12 uur per week willen werken, daarvoor beschikbaar zijn en daartoe tevens activieiten ontplooien. Volgens de officiële definitie van werkloze beroepsbevolking is slechts $17,6 \%$ werkloos, terwijl de cursisten zichzelf veel vaker als werkloos beschouwen $(38,1 \%)$. Verklaingen voor dit verschil zouden kunnen zijn dat sommige cursisten niet direct beschikbaar zijn voor de arbeidsmarkt of dat ze geen activiteiten ontplooien om werk te zoeken.

\subsection{Kenmerken huidige werkzaamheden}

Van de cursisten die betaald werk hebben, heeft het grootste deel van de cursisten NT2 $(63,7 \%)$ dit werk pas na het begin van de cursus gekregen, terwijl van de cursisten binnen de opleidingen gericht op BMF het grootste deel al betaald werk had (70,6\%). In de categorie NT2 zitten vooral allochtonen, voor wie het beheersen van de Nederlandse taal waarschijnlijk belangrijk is om een baan te kunnen krijgen. Van de werkenden heeft een aanzienlijk deel $(27,0 \%)$ een elementair beroep. De meeste werkenden hebben een dienstverband in loondienst $(64,6 \%)$. Een omvangrijk deel van de werkenden $(31,1 \%)$ heeft echter een flexibele aanstelling (aanstelling als uitzendkracht, oproepkracht e.d. of een aanstelling in tijdelijke dienst met een contract korter dan één jaar). Cursisten in de categorie NT2 hebben vaker een flexibele aanstelling $(40,0 \%)$ dan cursisten in de categorie BMF $(16,1 \%)$. lets minder dan de helft van de werkenden $(43,8 \%)$ heeft een deeltijdaanstelling (minder dan 33 uur betaald werk). Het bruto maandinkomen bedraagt gemiddeld FL. 2.448,--. Van de cursisten zegt bijna tweederde (64,2\%) wat te hebben gehad aan de cursus.

\subsection{Sociale redzaamheid}

Het blijkt dat de in de vragenlijst genoemde vaardigheden in verschillende mate een onderdeel vormen van de gevolgde SR-cursus. Indien de vaardigheid onderdeel van de cursus was, dan is zij in meer dan de helft van de gevallen tijdens de cursus daadwerkelijk geleerd. Een voorbeeld: rekenvaardigheid is in $29,7 \%$ van de gevallen onderdeel van de cursus geweest. Bij 70,3\% van de cursisten was rekenvaardigheid geen onderdeel van de cursus. Van de cursisten bij wie rekenvaardigheid onderdeel was van de cursus $(29,7 \%$ van de 276 cursisten $=82$ cursisten), heeft $74,4 \%(=61)$ deze vaardigheid daadwerkelijk geleerd .

Van de 277 cursisten SR heeft 89,2\% (= 247) zichzelf voorafgaand aan de cursus een doel gesteld. Van deze 247 cursisten heeft 64,8\% (=160) dit doel bereikt. Bovendien werd aan de cursisten, die voorafgaand aan de cursus een doel hebben gesteld, gevraagd wat voor hen het belangrijkste doel was. De antwoorden zijn in 11 doelen samengevat:

- om de kinderen te helpen, bij de tijd blijven;

- om leren gaan met computer;

- Nederlandse taal te beheersen om in Nederland te kunnen leven;

- Engels leren voor vakanties;

- lezen, schrijven, rekenen, schrijfvaardigheid verbeteren; 
- Nederlands verbeteren, nieuwe spelling;

- om een baan te krijgen/vinden, voor het starten van een eigen bedrijf/winkel;

- voor een vervolgopleiding;

- zelfredzaamheid (eigen administratie, maatschappelijk goed kunnen functioneren);

- overig (toekomst weer op te bouwen, voor de ontspanning, om meer eigenwaarde te krijgen, om beter voor zichzelf op te komen, interesse, om te kijken wat ik verder met mijn leven wil gaan doen, mensen leren kennen, contact met anderen, vrije tijdsbesteding);

- om wat te leren, voor eigen ontwikkeling, kennis ophalen/opfrissen.

Bij de belangrijkste doelen wordt naast de inhoud van de cursus (Nederlandse taal beheersen, om leren gaan met computer, Engels leren) ook het krijgen van een baan en het volgen van een vervolgopleiding genoemd. De meeste cursisten die zich een bepaald doel hebben gesteld, hebben dit doel ook bereikt. Alleen de cursisten die tot doel hadden een vervolgopleiding te gaan volgen, hebben niet zo vaak hun doel bereikt $(35,7 \%)$. Verder zeggen de meeste cursisten $(44,6+35,5=80,1 \%)$ wat gehad te hebben aan de cursus en iets minder dan de helft $(44,6 \%)$ zegt zelfs veel gehad te hebben aan de cursus.

\section{Besluit}

Er kunnen drie conclusies worden getrokken uit het hier uitgevoerde pilot-onderzoek onder cursisten van de Basiseducatie (BE). Allereerst is gebleken dat het vooraf indelen van de cursussen in de clusters Breed Maatschappelijk Functioneren (BMF), Sociale Redzaamheid (SR) en Nederlands als tweede taal (NT2) niet even gemakkelijk is geweest. De aangeleverde informatie door de ROC's was in dit opzicht niet even gedetailleerd. ROC's konden niet altijd aangeven in welk cluster een cursus valt. Bovendien worden voor cursussen soms verschillende indelingen gehanteerd. Zo kwam het voor dat soortgelijke cursussen bij het ene ROC tot een ander cluster van cursussen behoren dan bij het andere. Dit kan tot problemen leiden bij het vergelijken van overeenkomstige cursussen tussen verschillende ROC's.

Daarnaast kan de vragenlijst worden verbeterd door ook een vraag op te nemen over de maatschappelijke positie van de cursist voordat hij/zij aan de cursus begon. Hierdoor kan het effect van de cursus op de maatschappelijke positie van de cursist beter zichtbaar worden. Verder leert de ervaring dat de vragenlijst wat betreft taalgebruik nog eenvoudiger kan. Het kwam namelijk soms voor dat cursisten bepaalde woorden (bijvoorbeeld het woord initiatief) en zelfs sommige vragen (over het herkenbaar doorgeven van antwoorden aan de onderwijsinstelling) niet begrepen. Verder was de vraag over het geven van een rapportcijfer over de cursus niet duidelijk. Menig cursist dacht dat ze het rapportcijfer dat ze voor de cursus hadden behaald, moesten opgeven.

Ten slotte kan het telefonisch afnemen van de vragenlijst als positief worden beoordeeld. Het uiteindelijke responspercentage bedraagt $42 \%$. Dit is beduidend hoger dan eerder kleinschalig schriftelijk onderzoek onder cursisten van de Volwasseneducatie (VAVO) waar een respons van $30 \%$ is behaald. Het huidige responspercentage kan temeer worden gezien 6 
als succesvol, omdat de cursisten BE wegens taalproblemen waarschijnlijk moeilijker te bereiken zijn dan cursisten van de VAVO. 


\section{Bijlage 1 Kerngetallen cursussen Basiseducatie}

Tabel 1

Algemeen

\begin{tabular}{lcccc}
\hline & $B M F$ & $S R$ & $N T 2$ & Totaal \\
& & & & \\
\hline Geslacht & & & & \\
Man & $33,0 \%$ & $28,1 \%$ & $43,3 \%$ & $35,5 \%$ \\
Vrouw & $67,0 \%$ & $71,9 \%$ & $56,7 \%$ & $64,5 \%$ \\
Totaal (=100\%) & 176 & 295 & 335 & 807 \\
Leeftijd & & & & \\
$<35$ & $30,3 \%$ & $36,6 \%$ & $73,6 \%$ & $50,6 \%$ \\
$>35$ & $69,7 \%$ & $63,4 \%$ & $26,4 \%$ & $49,4 \%$ \\
Totaal (=100\%) & 175 & 295 & 333 & 803 \\
Allochtoon volgens & & & & \\
verbrede definitie WBEAA & & & & \\
Autochtoon & $67,0 \%$ & $60,2 \%$ & $25,9 \%$ & $49,6 \%$ \\
Allochtoon & $23,0 \%$ & $39,8 \%$ & $74,1 \%$ & $50,4 \%$ \\
Totaal (=100\%) & 174 & 294 & 332 & 800 \\
& & & & \\
\hline
\end{tabular}

Tabel 2

Gevolgde opleiding

$\begin{array}{llll}B M F & S R & N T 2 & \text { Totaal }\end{array}$

Gevolgde cursus

Oriëntatie/schakel cursussen

Computercursussen

Nederlands als tweede taal

Engels

Lezen, schrijven, rekenen

Nederlands voor autochtonen

Beroepsgerichte cursussen

Certificaten voortgezet onderwijs

Basale kennis/vaardigheden

Overige cursussen

Totaal $(=100 \%)$

$\begin{array}{rrrr}11,4 \% & 2,0 \% & 10,7 \% & 7,7 \% \\ 26,1 \% & 20,3 \% & 0,3 \% & 13,3 \% \\ 18,8 \% & 37,6 \% & 83,9 \% & 52,8 \% \\ 14,2 \% & 10,2 \% & 0,0 \% & 6,8 \% \\ 5,1 \% & 1,4 \% & 0,3 \% & 1,7 \% \\ 15,3 \% & 14,9 \% & 0,9 \% & 9,2 \% \\ 4,0 \% & 3,1 \% & 2,1 \% & 2,9 \% \\ 0,6 \% & 1,7 \% & 0,6 \% & 1,0 \% \\ 2,3 \% & 3,1 \% & 0,0 \% & 1,6 \% \\ 2,3 \% & 5,8 \% & 1,2 \% & 3,1 \% \\ 176 & 295 & 335 & 807\end{array}$

Tijdstip van cursus

Overdag

$\begin{array}{rrrr}65,9 \% & 73,6 \% & 77,7 \% & 73,6 \% \\ 30,1 \% & 22,7 \% & 15,2 \% & 21,2 \% \\ 4,0 \% & 3,7 \% & 7,1 \% & 5,2 \%\end{array}$

Combinatie

176

295

335

807 
Tabel 2 (vervolg)

Gevolgde opleiding

\begin{tabular}{lrrrr}
\hline & $B M F$ & \multicolumn{1}{c}{ SR } & NT2 & Totaal \\
& & & & \\
\hline Initiatief voor cursus & & & & \\
Werkgever & $2,8 \%$ & $2,0 \%$ & $2,7 \%$ & $2,5 \%$ \\
Arbeidsbureau & $6,8 \%$ & $2,7 \%$ & $8,3 \%$ & $5,9 \%$ \\
Sociale Dienst & $8,5 \%$ & $12,2 \%$ & $16,1 \%$ & $13,0 \%$ \\
Eigen initiatief & $72,2 \%$ & $75,3 \%$ & $65,8 \%$ & $70,6 \%$ \\
Anders (bijv. Gak) & $9,7 \%$ & $7,8 \%$ & $7,1 \%$ & $7,9 \%$ \\
Totaal (=100\%) & 176 & 295 & 335 & 807 \\
Cursusduur & & & & \\
Maanden & 14 & 13 & 14 & 14 \\
Totaal (=100\%) & 120 & 175 & 226 & 521 \\
Waardering voor cursus & & & & \\
Rapportcijfer (1-10) & 7,2 & 7,4 & 7,1 & 7,2 \\
Totaal (=100\%) & 168 & 276 & 306 & 750 \\
\hline
\end{tabular}

Tabel 3

Vervolgopleiding (niet gevraagd bij de categorie SR)

\begin{tabular}{lccc}
\hline & BMF & $\mathrm{NT2}$ & Totaal \\
& & & \\
\hline Deelname vervolgopleiding? & & & \\
Ja & $16,4 \%$ & $27,2 \%$ & $22,9 \%$ \\
Nee & $83,6 \%$ & $72,8 \%$ & $77,1 \%$ \\
Totaal (=100\%) & 171 & 316 & 487 \\
Niveau vervolgopleiding & & & \\
BE & & & \\
VAVO & $50,0 \%$ & $34,5 \%$ & $38,4 \%$ \\
MAVO/HAVO & $7,1 \%$ & $2,4 \%$ & $3,6 \%$ \\
VBO & $6,0 \%$ & $4,5 \%$ & $0,0 \%$ \\
BOL niveau 1/2 & & & \\
BOL niveau 3/4 & $3,6 \%$ & $4,8 \%$ & $4,5 \%$ \\
BBL niveau 1/2 & $21,4 \%$ & $23,8 \%$ & $23,2 \%$ \\
BBL niveau 3/4 & $3,6 \%$ & $1,2 \%$ & $1,8 \%$ \\
HBO & $0,0 \%$ & $5,9 \%$ & $4,5 \%$ \\
WO & $7,1 \%$ & $3,6 \%$ & $4,5 \%$ \\
Anders & $3,6 \%$ & $2,7 \%$ & $0,0 \%$ \\
Totaal (=100\%) & $7,1 \%$ & $14,3 \%$ & $12,5 \%$ \\
10 & & & \\
& 28 & 84 & 112 \\
& & &
\end{tabular}


Tabel 3 (vervolg)

Vervolgopleiding (niet gevraagd bij de categorie SR)

BMF NT2 Totaal

Vijf belangrijkste vervolgopleidingen

BE Kunst en Cultuur

$34,6 \% \quad 12,3 \% \quad 18,2 \%$

BE Techniek

BOL niveau $3 / 4$ Economie

BOL niveau 3/4 Techniek

$11,5 \% \quad 12,3 \% \quad 12,1 \%$

$15,4 \% \quad 11,0 \% \quad 12,1 \%$

BE Gedrag en Maatschappij

$3,8 \% \quad 6,8 \% \quad 6,1 \%$

$3,8 \% \quad 5,5 \% \quad 5,1 \%$

Totaal $(=100 \%)$

26

$73 \quad 99$

Nut van cursus voor

Vervolgopleiding

Veel

Gaat wel

Weinig

(Vrijwel) niets

$21,4 \%$

$21,4 \%$

$44,0 \%$

$48,2 \%$

$13,1 \% \quad 13,4 \%$

Totaal $(=100 \%)$

$3,6 \%$

$10,7 \%$

$8,9 \%$

28

84

112

Tabel 4

Bestemming

$\begin{array}{llll}\text { BMF } & \text { SR } & \text { NT2 } & \text { Totaal }\end{array}$

Belangrijkste bezigheid op dit moment

\section{Betaald werk}

Werkloos

Opleiding

Onbetaald werk/vrijwilligerswerk

Anders

Totaal $(=100 \%)$

Beroepsbevolking

Werkzame beroepsbevolking

Werkloze beroepsbevolking

Totaal (=100\%)

Ingeschreven bij arbeidsbureau?

$\mathrm{Ja}$

Nee

Totaal $(=100 \%)$

$\mathrm{x}=$ niet gevraagd voor de categorie SR

\begin{tabular}{|c|c|c|c|}
\hline $38,6 \%$ & $37,3 \%$ & $33,7 \%$ & $36,1 \%$ \\
\hline $42,6 \%$ & $40,1 \%$ & $34,0 \%$ & $38,1 \%$ \\
\hline $5,7 \%$ & $11,3 \%$ & $27,8 \%$ & $16,9 \%$ \\
\hline $6,8 \%$ & $2,4 \%$ & $2,4 \%$ & $3,4 \%$ \\
\hline $6,3 \%$ & $8,9 \%$ & $2,1 \%$ & $5,5 \%$ \\
\hline 176 & 292 & 335 & 803 \\
\hline $92,9 \%$ & $x$ & $77,8 \%$ & $82,4 \%$ \\
\hline $7,1 \%$ & $x$ & $22,2 \%$ & $17,6 \%$ \\
\hline 56 & $x$ & 126 & 182 \\
\hline $46,2 \%$ & $x$ & $64,8 \%$ & $61,5 \%$ \\
\hline $53,8 \%$ & $x$ & $35,2 \%$ & $38,5 \%$ \\
\hline 26 & $x$ & 122 & 148 \\
\hline
\end{tabular}


Tabel 5

Kenmerken huidige werkzaamheden

(alleen voor betaald werkenden, niet gevraagd bij de categorie SR)

\begin{tabular}{llll}
\hline BMF & NT2 & Totaal \\
\hline
\end{tabular}

Huidig werk gestart na begin cursus?

Ja

Nee

Totaal $(=100 \%)$

Vijf belangrijkste beroepsgroepen

Elementair beroep

Hulpkracht horeca/verzorging

Mechanisch operator

Verzorgend personeel

Receptionist/administratief employee

Totaal $(=100 \%)$

Aard van het dienstverband

Leer-arbeidsovereenkomst

Werk via uitzendbureau

Loondienst bij werkgever

Oproepkracht

Werkervaringsproject

Werk in bedrijf ouders/partner

Zelfstandige in eigen bedrijf/praktijk

Anders

Totaal $(=100 \%)$

Flexibele arbeidsrelatie?

$\mathrm{Ja}$

Nee

Totaal $(=100 \%)$

Deeltijdaanstelling?

$\mathrm{Ja}$

Nee

Totaal $(=100 \%)$

Bruto maandinkomen

Totaal $(=100 \%)$

Nut van cursus voor huidige functie

Veel

Gaat wel

Weinig

(Vrijwel) niets

Totaal $(=100 \%)$

$\begin{array}{lll}29,4 \% & 63,7 \% & 33,4 \% \\ 70,6 \% & 36,3 \% & 66,6 \%\end{array}$

$\begin{array}{lll}68 & 113 & 181\end{array}$

$22,1 \% \quad 30,0 \% \quad 27,0 \%$

$11,8 \% \quad 10,9 \% \quad 11,2 \%$

$2,9 \% \quad 8,2 \% \quad 6,2 \%$

$7,4 \% \quad 5,5 \% \quad 6,2 \%$

$7,4 \% \quad 4,5 \% \quad 5,6 \%$

$\begin{array}{lll}68 & 110 & 178\end{array}$

$1,5 \% \quad 6,3 \% \quad 4,5 \%$

$4,5 \% \quad 21,6 \% \quad 15,2 \%$

$71,6 \% \quad 60,4 \% \quad 64,6 \%$

$6,0 \% \quad 4,5 \% \quad 5,1 \%$

$4,5 \% \quad 0,9 \% \quad 2,2 \%$

$1,5 \% \quad 0,0 \% \quad 0,6 \%$

$9,0 \% \quad 3,6 \% \quad 5,6 \%$

$1,5 \% \quad 2,7 \% \quad 2,2 \%$

$\begin{array}{lll}67 & 111 & 178\end{array}$

$16,1 \% \quad 40,0 \% \quad 31,1 \%$

$83,9 \% \quad 60,0 \% \quad 68,9 \%$

$\begin{array}{lll}62 & 105 & 167\end{array}$

$50,8 \% \quad 39,8 \% \quad 43,8 \%$

$49,2 \% \quad 60,2 \% \quad 56,2 \%$

$\begin{array}{lll}61 & 108 & 169\end{array}$

FI. $2078 \quad$ Fl. $2605 \quad$ FI. 2448

$\begin{array}{lll}30 & 71 & 101\end{array}$

$23.9 \% \quad 30.4 \% \quad 27.9 \%$

$34.3 \% \quad 37.5 \% \quad 36.3 \%$

$14.9 \% \quad 15.2 \% \quad 15.1 \%$

$26.9 \% \quad 17.0 \% \quad 20.7 \%$

$\begin{array}{lll}67 & 112 & 179\end{array}$ 
Tabel 6

Sociale Redzaamheid (alleen SR)

Onderdeel van cursus $\%$ ja

Rekenvaardigheid

Schrijfvaardigheid

Spreekvaardigheid

Leesvaardigheid

Zelfstandig leren

Omgaan met computers

Nauwkeurig werken

Oplossen van problemen

Omgaan met anderen

Opkomen voor eigen mening

Omgaan met emoties

Samenwerken met anderen

Zelfstandig worden

Initiatief durven nemen

Totaal $(=100 \%)$

Doelstelling van cursus

Doel gesteld

Totaal $(=100 \%)$

Belangrijkste doelen

Nederlandse taal beheersen

Om leren gaan met de computer

Een baan krijgen

Engels leren

Volgen van een vervolgopleiding

Zelfredzaamheid

Totaal $(=100 \%)$

Nut van cursus

Veel

Gaat wel

Weinig

(vrijwel) niets

Totaal $(=100 \%)$
$29,7 \%$

$75,8 \%$

$63,9 \%$

$74,4 \%$

$68,7 \%$

$50,4 \%$

$54,5 \%$

$45,9 \%$

$52,4 \%$

$43,9 \%$

$22,0 \%$

$56,2 \%$

$44,8 \%$

$46,1 \%$

276

Vooraf doel gesteld $\%$ ja

$89,2 \%$

277

Indien vooraf doel gesteld $\%$ belangrijkste doelen

$25,2 \%$

$13,8 \%$

$13,4 \%$

$6,9 \%$

$6,1 \%$

$6,1 \%$

246

$44,6 \%$

$35,5 \%$

$14,1 \%$

$5,8 \%$

276
Indien onderdeel van cursus

$\%$ daadwerkelijk geleerd

$74,4 \%$

$81,9 \%$

$84,7 \%$

$84,4 \%$

$4,2 \%$

$85,6 \%$

$77,9 \%$

$77,7 \%$

$76,6 \%$

$73,0 \%$

$61,4 \%$

$77,2 \%$

$76,7 \%$

$72,9 \%$

Indien vooraf doel gesteld

$\%$ doel bereikt

$64,8 \%$

Indien dat doel gesteld

$\%$ dat doel bereikt

$53,2 \%$

$66,7 \%$

$57,6 \%$

$64,7 \%$

$35,7 \%$

$93,3 \%$ 


\section{Bijlage 2 Telefonische vragenlijst Basiseducatie (BMF, NT2 en SR)}

\section{Introductie}

(enq: korte inleiding over hoe en waarom, plus tijdsinschatting van de enquête geven)

\section{Gevolgde opleiding}

1. Heeft $u$ in de periode december 1997 - juli 1998 bij .............. (enq: naam ROC noemen) een cursus in het kader van de basiseducatie verlaten. Zo ja, wat is de naam van deze cursus?

(GO1)

1 ja, namelijk: (enq: ga naar vraag 3)

2 nee

2. Heeft $u$ in deze periode soms een andere cursus bij (enq: naam ROC noemen) verlaten? Zo ja, wat is de naam van deze cursus? (GO1)

1 ja, namelijk:

2 nee (enq: einde van het interview)

3. Heeft u deze cursus overdag of 's avonds gevolgd?

(GOOA)

1 overdag

2 's avonds

3 combinatie van overdag en 's avonds

4. Op wiens initiatief bent $u$ deze cursus gaan volgen? Is dat op initiatief van: (enq: noem de verschillende mogelijkheden)

(GOINIT, GOINIT1)

1 werkgever

2 arbeidsbureau

3 sociale dienst

4 uzelf

5 anders, namelijk:

5. Wanneer bent u met deze cursus begonnen? (enq: vraag naar de maand en het jaar) (GOBGM, GOBGJ)

maand:

jaar: 
6. Wanneer heeft u deze cursus verlaten? (enq: vraag naar de maand en het jaar) (GOEIM, GOEIJ)

maand:

jaar:

\section{Vervolgonderwijs}

(enq: indien vooraf bekend is dat de gevolgde cursus SR is, ga dan naar vraag 11)

7. Bent u ná het verlaten van de cursus een vervolgopleiding gaan doen? (enq: maak duidelijk dat het hier niet gaat om een cursus of bedrijfsopleiding; het kan wel om (een of meerdere vakken van) een opleiding VAVO gaan)

(VVOGEV)

1 ja

2 nee (enq: ga naar vraag 11)

Indien u na het verlaten van de cursus meerdere vervolgopleidingen heeft gevolgd, dan gaan de volgende vragen alléén over de eerste vervolgopleiding.

8. Wat is de officiële naam van deze vervolgopleiding? Geef zowel het schooltype als de opleidingsrichting aan. (enq: geef de respondent voorbeelden: reguliere VWO, MBO (BOL) bedrijfsadministratie, leerlingwezen (BBL) informatietechniek, HBO informatica, WO Psychologie)

(VVO)

1 VAVO:

2 reguliere MAVO

3 reguliere HAVO

4 reguliere $\mathrm{VWO}$

5 VBO:

$6 \mathrm{MBO}(\mathrm{BOL})$ :

7 leerlingwezen (BBL):

$8 \mathrm{HBO}:$

9 WO:

10 anders, namelijk:

(enq: indien de respondent naar $\mathrm{MBO}(\mathrm{BOL})$ of leerlingwezen $(\mathrm{BBL})$ is gegaan, ga dan naar vraag 9a; ga in alle andere gevallen naar vraag 10)

9a. Welk niveau vervolgopleiding volgt/volgde $u$ ? Is dat een: (enq: mogelijkheden opnoemen)

(VVOSRT) 
1 assistentenopleiding (assistent beroepsbeoefenaar) (niveau 1)

2 basisberoepsopleiding (beginnend beroepsbeoefenaar) (niveau 2)

3 vakopleiding (zelfstandig beroepsbeoefenaar) (niveau 3)

4 middenkaderopleiding (kaderfunctionaris) (niveau 4a)

5 specialistenopleiding (gespecialiseerd beroepsbeoefenaar) (niveau 4b)

9b. Volgt/volgde $u$ de beroepsopleidende (MBO-dagopleiding (BOL)) of de beroepsbegeleidende (leerlingwezen (BBL)) leerweg?

(VVOLWG)

1 beroepsopleidende leerweg (enq: ga naar vraag 10)

2 beroepsbegeleidende leerweg (enq: ga naar vraag 9c)

9c. Heeft of had $u$ in het kader van uw vervolgopleiding in het leerlingwezen werk of een stageplaats (beroepspraktijkvorming (BPV))? Zo ja, is/was dat betaald werk of $\mathrm{krijgt} / \mathrm{kreeg} \mathrm{u}$ een onkosten- of stagevergoeding?

(VVOWK)

$1 \mathrm{ja}$, betaald werk

2 ja, werk of stage met alleen onkosten- of stagevergoeding

$3 \mathrm{ja}$, onbetaald werk

4 nee, volg(de) alleen schoolgedeelte

10. Wat heeft $u$ aan de gevolgde cursus gehad voor uw vervolgopleiding?

(VVONUT)

1 veel

2 gaat wel

3 weinig

4 (vrijwel) niets

\section{Bestemming}

11. Wat is uw belangrijkste dagelijkse bezigheid op dit moment? Is dat: (enq: noem de verschillende mogelijkheden; slechts één antwoord mogelijk) (MPAND, MPE)

1. betaald werk (enq: ga naar vraag 12)

2. werkloos (enq: ga naar vraag 18)

3. opleiding (enq: ga naar vraag 26)

4. onbetaald werk/vrijwilligerswerk (enq: indien vooraf bekend is dat de gevolgde cursus NT2 of BMF is, ga dan naar vraag 26; ga anders naar vraag 23)

5. anders, namelijk: ................. (enq: indien vooraf bekend is dat de gevolgde cursus NT2 of BMF is, ga dan naar vraag 26; ga anders naar vraag 23) 
(enq: indien vooraf bekend is dat de gevolgde cursus SR is, ga dan altijd naar vraag 23)

\section{Kenmerken huidige werkzaamheden}

12. Wanneer bent $u$ bij het bedrijf of organisatie waar $u$ nu werkt begonnen? (enq: vraag naar de maand en het jaar)

(HBGM, HBGJ)

maand:

jaar:

13a. Wat is de officiële naam van uw huidige functie? (enq: bv. lasser, verkoper, automonteur, metselaar, ober, secretaresse, ziekenverzorgende) (HBER)

13b. Wat zijn uw voornaamste werkzaamheden? (enq: bv. technisch tekenen, verkopen van kleding, schilderen, bloemen telen, boekhouden) (HBER)

13c. In wat voor bedrijf of organisatie werkt $u$ ? (enq: bv. machinefabriek, garagewerkplaats, kledingwinkel, hotel, ziekenhuis) (HBRA)

13d. Wat voor soort product of dienst levert het bedrijf of organisatie voornamelijk? (enq: bv. landbouwmachines, bouwtechnisch advies, drukwerk, medische verzorging)

(HBRA)

14. In wat voor soort dienstverband werkt $u$ ? Is dat: (enq: noem de verschillende mogelijkheden)

(HDVB1L, HDVB2)

1 leer-arbeidsovereenkomst (via leerlingwezen/beroepsbegeleidende leerweg)

2 werk via uitzendbureau

3 loondienst bij werkgever

4 oproepkracht, 0 -uren- of min-/max contract

5 werkervaringsproject (via WIW; bv. JWG)

6 werk in bedrijf ouders/partner

7 zelfstandige in eigen bedrijf/praktijk (incl. maatschap) of free-lance

8 anders, namelijk:

15a. Heeft een vaste of een tijdelijke aanstelling? (enq: indien tijdelijk, vraag ook naar de duur van het contract en of er uitzicht is op een vaste aanstelling) 
(HASD, HASDM)

1 tijdelijke aanstelling voor ..... maanden, zonder uitzicht op vaste baan

2 tijdelijke aanstelling voor ..... maanden, met uitzicht op vaste baan

3 vaste aanstelling of proeftijd voor vaste baan

15b. Wat heeft $u$ aan de gevolgde cursus gehad voor uw huidige functie?

(HNUT)

1 veel

2 gaat wel

3 weinig

4 (vrijwel) niets

16. Mag ik u vragen hoeveel $u$ verdient in uw huidige functie? Is dat bruto of netto? En is dat per maand, per vier weken of per week? (enq: toeslagen onregelmatige dienst, fooi, provisie e.d. meetellen; overwerk, vakantiegeld, 13e maand, uitkering, (studie)beurs e.d. niet meetellen; bij wisselende verdiensten uitgaan van het gemiddelde; indien respondent geen antwoord wil geven, dan niet doorvragen).

(HBIZP, HBIPER, HNIZP, HNIPER)

1 bruto:

gulden per 1 maand

2 netto:

2 vier weken

3 week

17. Hoeveel uur per week werkt $u$ (volgens het contract) in uw functie? (enq: eventuele arbeidsduurverkorting (ADV) van het wekelijks aantal uren aftrekken, overwerk en eventuele nevenfuncties niet meetellen; bij wisselende werkweken uitgaan van het gemiddelde)

(HAU)

per week: ......... arbeidsuren

(enq: indien 12 of meer uren per week, ga dan naar vraag 26)

\section{Werkzoekend}

18. Bent u momenteel op zoek naar (ander) betaald werk? Zo ja, hoeveel uur per week zou u willen werken? (enq: 'ander' geldt alleen als respondent betaald werk, minder dan 12 uur per week heeft)

(BWZK, BWGAU)

1 ja, voor ...... uur per week

2 nee 
19. Heeft $u$ in de afgelopen vier weken iets gedaan om aan (ander) betaald werk te komen? Zo nee, wacht u op de uitkomst van lopende sollicitatie(s)? (enq: 'ander' geldt alleen als respondent betaald werk, minder dan 12 uur per week heeft) (BWZK4W)
1 ja
2 nee
3 nee, maar ik wacht op uitkomst van lopende sollicitatie(s)

20. Als u nú een (andere) baan zou vinden, wanneer kunt $u$ daarmee dan beginnen? (enq: 'andere' geldt alleen als respondent betaald werk, minder dan 12 uur per week heeft)

(BWBSB)

1 binnen 2 weken (enq: ga naar vraag 22)

2 tussen 2 weken en 3 maanden (enq: ga naar vraag 21)

3 na 3 maanden (enq: ga naar vraag 21 )

21. Waarom kunt u niet eerder beginnen?

(BWNBG1, BWNBG2)

1 opzeggen huidige baan

2 afronden vrijwilligerswerk

3 afronden opleiding/studie

4 regelen kinderopvang

5 vakantie

6 ziekte

7 andere reden, namelijk:

22. Bent $u$ ingeschreven bij het arbeidsbureau?

(ARBBUR)

1 ja

2 nee

(enq: indien vooraf bekend is dat de gevolgde cursus NT2 of BMF is, ga naar dan vraag 26; ga anders naar vraag 23 )

\section{Sociale redzaamheid}

23. Wat is het belangrijkste dat $u$ tijdens de cursus heeft geleerd? (CBOBLG) 
24. Ik noem u nu enkele vaardigheden op die betrekking kunnen hebben op de door u gevolgde cursus.

a. Vormden de genoemde vaardigheden onderdeel van de cursus?

(CBOORKV, CBOOSPRS, CBOOMPRS, CBOOLSV, CBOOZLR, CBOOCOMP, CBOONZ, CBOOOPL, CBOOOA, CBOOMEN, CBOOEMO, CBOOSW, CBOOZWR, CBOOINIT)

b. Zo ja, heeft $u$ de genoemde vaardigheden geleerd tijdens de cursus? (enq: dus alleen vragen als de betreffende vaardigheid onderdeel is van de cursus)

(CBOGRKV, CBOGSPRS, CBOGMPRS, CBOGLSV, CBOGZLR, CBOGCOMP, CBOGNZ, CBOGOPL, CBOGOA, CBOGMEN, CBOGEMO, CBOGSW, CBOGZWR, CBOGINIT)
a. Onderdeel van cursus?
b. Geleerd?
ja nee
ja nee

Vaardigheden:

rekenvaardigheid

schrijfvaardigheid

spreekvaardigheid

leesvaardigheid

zelfstandig leren

omgaan met computers

nauwkeurig werken

oplossen van problemen

omgaan met anderen

opkomen voor eigen mening

omgaan met emoties

samenwerken met anderen

zelfstandig worden

initiatief durven nemen

25a. Bent $u$ de cursus gaan volgen met een bepaald doel?

(CBOGEV)

1 ja (enq: ga naar vraag 25b)

2 nee (enq: ga naar vraag 25c)

25b. Welk doel was dat en heeft u dit doel bereikt?

(CBODOEL, CBODOEL1)

doel:

1 doel bereikt

2 doel niet bereikt

25c. Wat heeft $u$ aan de gevolgde cursus gehad? 
(CBONUT)

1 veel

2 gaat wel

3 weinig

4 (vrijwel) niets

\section{Oordeel gevolgde cursus}

26. Ik wil graag dat u een rapportcijfer geeft voor de cursus als geheel. Welk cijfer is dat? (enq: het gaat om een afgerond cijfer tussen 1 en 10) (MGOTOT)

cijfer:

\section{Algemeen}

Ten slotte wil ik u nog enkele algemene vragen voorleggen.

27. U bent een:

(GESL)

1 man

2 vrouw

28. Wat is uw leeftijd?

(LFT)

jaar

29. In welk land bent u geboren?

(GBLNDRP1, GBLNDRP2)

1 Nederland

2 ander land, namelijk:

30a. In welk land is uw vader geboren?

(LNDPA1, LNDPA2)

1 Nederland

2 ander land, namelijk:

30b. In welk land is uw moeder geboren?

(LNDMA1, LNDMA2) 
1 Nederland

2 ander land, namelijk:

31. Welke taal wordt bij u thuis gesproken?

(TAAL1, TAAL2)

1 Nederlands

2 anders, namelijk:

32. Mogen uw antwoorden herkenbaar aan uw vroegere school worden doorgegeven? (GEGDG)

$1 \mathrm{ja}$, ik vind dit goed

2 nee, ik vind dit niet goed

33. Heeft u zelf nog vragen of opmerkingen?

(OPM)

Dit waren de vragen. Bedankt voor uw medewerking! 